\title{
Biophysical modeling of excitability and membrane integration at the single cell and network levels
}

\author{
Marco Arieli Herrera-Valdez ${ }^{1,2,3^{*}}$, Adrian Smith ${ }^{1,2,3}$, Maytee Cruz-Aponte ${ }^{1,2}$, Erin C McKiernan ${ }^{1}$ \\ From Twentieth Annual Computational Neuroscience Meeting: CNS*2011 \\ Stockholm, Sweden. 23-28 July 2011
}

Ion channels facilitate the diffusion of specific ions across neuronal membranes. If large enough, this movement of charge creates currents that may change the membrane potential. Biophysical models of membrane potential assume the trans-membrane currents flow within an "equivalent electrical circuit" in which ion channels are represented by resistors arranged in parallel. The functions representing the trans-membrane currents mediated by channels are typically written using Ohm's law. It is possible to describe channel-mediated currents by taking diffusion into consideration [1], but such formulations are not widely used in the literature. Here we present a model of membrane potential in which channel gating and current density are derived from first principles of thermodynamics, assuming that currents are produced by electrodiffusion. These models display properties that cannot be observed in conductance-based models, such as rectification of membrane currents. Guidelines for parameter estimation, and specific rules to adjust the model against experimental data, are presented along with examples of parameter regimes that yield representations of specific electrophysiological signatures with a biophysically sound baseline. Bifurcation analysis is used to describe transitions between qualitatively different behaviors of the model and link them to functionally relevant properties observable in neurons of different types. Network extensions are constructed using realistic synaptic input and local field potential oscillations to illustrate how networks may display potentially different responses to afferent input depending on the intrinsic properties of the participating

\footnotetext{
* Correspondence: Marco.Herrera-Valdez@asu.edu

${ }^{1}$ Mathematical, Computational, and Modeling Sciences Center, Arizona State University, Tempe, AZ 85287, USA

Full list of author information is available at the end of the article
}

neurons. The electrodiffusion formulation presented here constitutes a theoretical improvement over conductance-based models that may advance our current understanding of dynamical behavior in single cells and networks.

\section{Acknowledgements}

We thank Joceline Lega and Andrew J. Fuglevand for their useful comments.

\section{Author details}

'Mathematical, Computational, and Modeling Sciences Center, Arizona State University, Tempe, AZ 85287, USA. ${ }^{2}$ School of Evolution and Social Change, Arizona State University, Tempe, AZ 85287, USA. ${ }^{3}$ School of Life Sciences, Arizona State University, Tempe, AZ 85287, USA.

Published: 18 July 2011

\section{Reference}

1. Goldman DE: Potential, impedance, and rectification in membranes. The Journal of General Physiology 1943, 27(20).

doi:10.1186/1471-2202-12-S1-P218

Cite this article as: Herrera-Valdez et al:: Biophysical modeling of excitability and membrane integration at the single cell and network levels. BMC Neuroscience 2011 12(Suppl 1):P218.

Submit your next manuscript to BioMed Central and take full advantage of:

- Convenient online submission

- Thorough peer review

- No space constraints or color figure charges

- Immediate publication on acceptance

- Inclusion in PubMed, CAS, Scopus and Google Scholar

- Research which is freely available for redistribution

\section{Ciomed Central}

